\title{
Xanthomonas fuscans subsp. fuscans causing wilt symptoms in bean plants (Phaseolus vulgaris) in Brazil
}

\author{
Xanthomonas fuscans subsp. fuscans causando sintomas de murcha em \\ feijoeiro (Phaseolus vulgaris) no Brasil
}

\author{
Irene Maria Gatti de Almeida ${ }^{1 *}$, Lucas Matheus Rivero Rodrigues ${ }^{2}$, Luís Otávio Saggion Beriam ${ }^{1}$
}

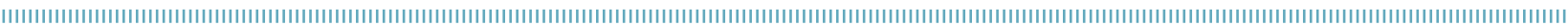

\begin{abstract}
Common and fuscous blights of bean are diseases widely distributed in the world. The most commonly observed symptoms are spots on leaves, stems, pods and seeds. In December 2009, bean plants cv. Uirapuru showing symptoms of wilt similar to those induced by Curtobacterium flaccumfaciens pv. flaccumfaciens were observed in a commercial crop located in the county of Itararé, State of São Paulo, Brazil. The plants were at the last cycle stage with mature pods and these symptoms were noted in the majority of the growing area. Optical microscopic observations of discolored vascular tissue from diseased stems revealed the presence of bacterial masses oozed from infected tissue, indicating that the disease was caused by bacterial pathogen. Isolations on nutrient agar showed circular, convex, yellow colonies with smooth edges. The causal bacterium was Gramnegative and produced a dark brown pigment in culture medium. Biochemical, cultural and physiological tests confirmed its identity as Xanthomonas fuscans subsp. fuscans (syn. Xanthomonas campestris pv. phaseoli "var. fuscans"). The pathogenicity of the isolates was confirmed by artificial inoculations. Systemic infection has been reported in the literature but these kinds of symptoms are not currently observed in Brazilian fields. Bacterial strains were deposited on the Phytobacteria Culture Collection of Instituto Biológico (IBSBF - www.biologico.sp.gov.br/bacterias/ php) under accession numbers 2813 and 3028.
\end{abstract}

KEYWORDS: bacterial blight; systemic infection; Xanthomonas axonopodis pv. phaseoli.
RESUMO: O crestamento bacteriano comum do feijoeiro é uma doença amplamente distribuída no mundo e os sintomas comumente observados são manchas nas folhas, hastes, vagens e sementes. Em dezembro de 2009, plantas de feijoeiro cv. Uirapuru com sintomas de murcha similares aos produzidos por Curtobacterium flaccumfaciens pv. flaccumfaciens foram observadas em campos comerciais localizados no município de Itararé, estado de São Paulo, Brasil. As plantas encontravam-se no final do ciclo, com as vagens já formadas. Os sintomas foram notados em quase a totalidade da área cultivada. Observaçóes ao microscópio óptico de fragmentos de tecido do sistema vascular das hastes de plantas doentes evidenciaram intenso fluxo bacteriano, confirmando tratar-se de doença bacteriana. Isolamentos realizados em meio nutriente ágar produziram colônias de coloraçáo amarelada, brilhantes, convexas, lisas. A bactéria agente causal era Gram-negativa e produtora de pigmento marrom escuro em meio de cultura. Testes bioquímicos, culturais e fisiológicos confirmaram sua identidade como Xanthomonas fuscans subsp. fuscans (sin. Xanthomonas campestris pv. phaseoli "var. fuscans"). A patogenicidade dos isolados foi confirmada por inoculaçóes artificiais em mudas de feijão cv. Carioca e os reisolamentos efetuados resultaram em colônias semelhantes às originais. Embora descrita na literatura, a infecção sistêmica não é usualmente observada nos plantios de feijoeiro em nosso país. Linhagens bacterianas encontram-se depositadas na Coleção de Culturas do Instituto Biológico (IBSBF) sob os números 2813 e 3028.

PALAVRAS-CHAVE: crestamento bacteriano; infecção sistêmica; Xanthomonas axonopodis pv. phaseoli. 
Common and fuscous blights of bean are serious and widespread diseases in most bean-growing areas of the world. The disease can be highly destructive during extended periods of warm and humid weather, causing reductions in both yield and seed quality. In Brazil, it has been the cause of several great losses in productive growing areas, especially during the summer. The most commonly observed symptoms of infection are initially small, water soaked leaf spots becoming necrotic, light brown, usually surrounded by chlorotic haloes. Lesions often coalesce and cause extensive tissue damage. These symptoms could be seen in the stems, pods and seeds. Systemic infection can also occur on susceptible cultivars (Bianchini et al., 2005).

According to the literature, the pathogen associated with this disease was classified as Xanthomonas campestris pv. phaseoli at the 1980's. However, since some bacterial strains can cause darkening of the culture medium, it was also named $X$. campestris pv. phaseoli "var. fuscans". In 1995, VAUTERIN et al. (1995) published a reclassification of the genus Xanthomonas and this bacterium was allocated as $X$. axonopodis pv. phaseoli. SCHAAD et al. $(2005,2006)$ proposed Xanthomonas fuscans subsp. fuscans for the fuscous blight pathogen.

The pathogen can survive on the soil surface and as an epiphyte on several weeds and it is usually introduced to new regions via contaminated seed. Secondary spread can occur by wind-blown rain, overhead irrigation, contaminated equipment, or people and animals.

Two other bacteria have already been described causing wilt symptoms in beans: Ralstonia solanacearum and Curtobacterium flaccumfaciens pv. flaccumfaciens. In Brazil,
Ralstonia solanacearum was reported for the first time in 1980 in the State of Rio de Janeiro (Акiвa et al., 1980) and Curtobacterium flaccumfaciens pv. flaccumfaciens, in 1997, in the State of Sáo Paulo (Maringoni; Rosa 1997).

In December 2009, bean plants cv. Uirapuru showing wilt symptoms similar to bacterial wilt induced by Curtobacterium flaccumfaciens pv. flaccumfaciens were observed in commercial fields located at the county of Itararé, State of São Paulo, Brazil. The plants were at the last stage of the cycle with mature pods (Fig. 1) and these symptoms were noted in the majority of the growing area.

Optical microscopic observations of longitudinal sections of stems with discolored vascular tissue revealed the presence of intense bacterial masses streamed from the infected tissue, indicating that the disease was caused by bacterial pathogen.

Bacteria isolation was performed by macerating small pieces of diseased tissues in sterile distilled water and the resulting suspension was streaked on nutrient agar medium (NA) (Levine, 1954).

Detection of the causal agent was also made in seed samples collected from the pods of the diseased plants received for analysis. Bacteria were extracted from seeds by soaking the samples in sterile saline solution $(0.85 \%$ $\mathrm{NaCl})$ for $16 \mathrm{~h}$ at $4^{\circ} \mathrm{C}$. Aliquots of $100 \mu \mathrm{L}$ of the seed leachate were plated on NA medium containing $10 \mu \mathrm{g} / \mathrm{L}$ of the fungicide chlorothalonil.

After incubation at $28^{\circ} \mathrm{C}$ for $48-72 \mathrm{~h}$, yellow, mucoid, glistening, convex, smooth bacterial colonies, characteristic of the genus Xanthomonas, were observed in both isolations, from diseased tissue and seeds (Fig. 1B).
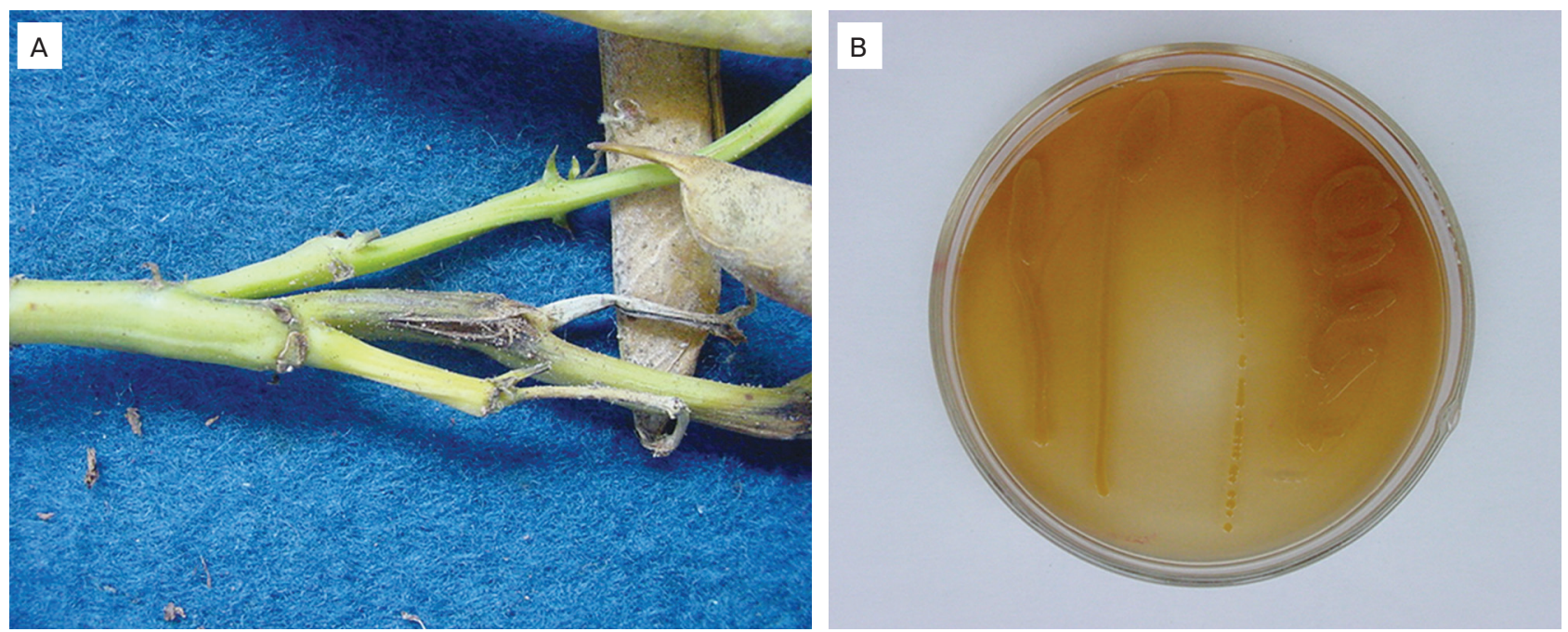

Figure 1. Xanthomonas fuscans subsp. fuscans in bean. (A) Natural infection. Longitudinal section of stem showing vascular discoloration of the vessels; (B) purified colonies onto culture medium. Note the darkening of the medium. 
The bacterial isolates were tested for pathogenicity through inoculations performed by spraying suspensions containing ca. $10^{8} \mathrm{CFU} / \mathrm{mL}$ on previously wounded leaves of 15-day-old bean seedlings cv. Carioca. Control plants were similarly treated using sterile distilled water. The inoculated plants were kept under moist chamber conditions for $72 \mathrm{~h}$.

Symptoms of necrotic lesions on leaves and petioles could be seen 10-15 days after inoculation. Control plants remained healthy. Re-isolations resulted in bacterial colonies similar to the originals.

Results of the cultural, biochemical and physiological tests (Bradbury, 1986; SchaAd et al., 2001) confirmed the identity of the bacterium as Xanthomonas fuscans subsp. fuscans (syn. Xanthomonas campestris pv. phaseoli "var. fuscans") (Table 1).

According to the literature, common bean cv. Uirapuru was susceptible to curtobacterium wilt and common bacterial blight diseases. However, the bacterial isolates were Gram-negative, induced hypersensitivity reaction in tomato leaves and produced a diffusible dark brown pigment in the culture medium, indicating that Curtobacterium flaccumfaciens pv. flaccumfaciens could not be the causative agent of the observed symptoms but Xanthomonas fuscans subsp. fuscans.

Bacterial strains were deposited at the Phytobacteria Culture Collection of Instituto Biológico (IBSBF - www. biologico.sp.gov.br/bacterias/php) under accession numbers 2813 and 3028 .
Table 1. Biochemical and physiological characteristics of Xanthomonas fuscans subsp. fuscans (X.f.f.) and the bean isolates.

\begin{tabular}{lcc} 
& \multicolumn{2}{c}{ Cultures } \\
\cline { 2 - 3 } Characteristics & X.f.f. & Bean isolates \\
\hline Catalase & +1 & + \\
\hline Oxidase & -1 & - \\
\hline Oxidative/fermentative reaction & $0^{1}$ & 0 \\
\hline Hypersensitivity reaction on tobacco & - & - \\
\hline Hypersensitivity reaction on tomato & + & + \\
\hline Asparagine growth & - & - \\
\hline $\mathrm{H}_{2}$ S from cystein & + & + \\
\hline Indol production & - & - \\
\hline Nitrate reduction & - & - \\
\hline Christensen's urease & - & - \\
\hline Tween 80 hydrolysis & + & + \\
\hline Starch hydrolysis & + & + \\
\hline Gelatin hydrolysis & - & - \\
\hline Acid production from: & & \\
\hline arabinose, cellobiose, fructose & + & + \\
\hline galactose, glycerol, mannose & + & + \\
\hline sucrose, threalose & + & + \\
\hline adonitol, dulcitol, inulin & - & - \\
\hline alpha-m-D-glucoside, inositol & - & - \\
\hline rhamnose, raffinose & - & - \\
\hline salicin, sorbitol & - & - \\
\hline Oganic acid utilization: & & - \\
\hline acetate, citrate, succinate & + & - \\
\hline benzoate, malonate, oxalate & - & - \\
\hline tartrate & - & - \\
\hline Acetoin production & - & - \\
\hline Growth at $41^{\circ} \mathrm{C}$ & - & - \\
\hline : oxidative, & positive reaction; & - \\
\hline
\end{tabular}

O: oxidative; +: positive reaction; -: negative reaction

\section{REFERENCES}

AKIBA, F.; KIMURA, O.; PIMENTEL, J.P.; RIBEIRO, R.L.D.; ROBBS, C.F. "Murcha bacteriana" do feijão vagem: doença nova para o Brasil. Fitopatologia Brasileira, v.6, p.379, 1980.

BIANCHINI, A.; MARINGONI, A.C.; CARNEIRO, S.M.T.P.G.. Doenças do feijoeiro. In: KIMATI, H.; AMORIM, L.; BERGAMIN FILHO, A.; CAMARGO, L.E.A.; REZENDE, J.A.M. Manual de Fitopatologia: doenças das plantas cultivadas. v.2. São Paulo: Agronômica Ceres, 2005. p.376-399.

BRADBURY, J.F. Guide to plant pathogenic bacteria. Kew: CAB International, 1986. 332p.

LEVINE, M. An introduction to laboratory technique in bacteriology. New York: MacMillan, 1954.

MARINGONI, A.C.; ROSA, E.F. Ocorrência de Curtobacterium flaccumfaciens pv. flaccumfaciens em feijoeiro no estado de São Paulo. Summa Phytopatologica, v.23, n.2, p.160-162, 1997.

SCHAAD, N.W.; JONES, J.B.; CHUN, W. (Eds.) Laboratory guide for identification of plant pathogenic bacteria. $3^{\text {rd }}$ ed. St. Paul: APS Press, 2001. 373p.
SCHAAD, N.W.; POSTNIKOVA, E.; LACY, G.; SECHLER, A.; AGARKOVA, I.; STROMBERG, P.E.; STROMBERG, V.K.; VIDAVER, A.K. Reclassification of Xanthomonas campestris pv. citri (ex Hasse 1915) Dye 1978 forms $A, B / C / D$, and $E$ as $X$. smithii subsp. citri (ex Hasse) sp. nov. nom. rev. comb. nov., $X$. fuscans subsp. aurantifolii (ex Gabriel 1989) sp. nov. nom. rev. comb. nov., and X. alfalfae subsp. citrumelo (ex Riker and Jones) Gabriel et al., 1989 sp. nov. nom. rev. comb. nov.; $X$. campestris pv. malvacearum (ex Smith 1901) Dye 1978 as $X$. smithii subsp. smithii nov. comb. nov. nom. nov.; $X$. campestris pv. alfalfae (ex Riker and Jones, 1935) Dye 1978 as $X$. alfalfae subsp. alfalfae (ex Riker et al., 1935) sp. nov. nom. rev.; and "var. fuscans" of $X$. campestris pv. phaseoli (ex Smith, 1987) Dye 1978 as $X$. fuscans subsp. fuscans sp. nov. Systematic and Applied Microbiology, v.28, n.6, p.494-518, 2005.

SCHAAD, N.W.; POSTNIKOVA, E.; LACY, G.; SECHLER, A.; AGARKOVA, I.; STROMBERG, P.E.; STROMBERG, V.K.; VIDAVER, A.K. Emended classification of xanthomonad pathogens on citrus. Systematic and Applied Microbiology, v.29, n.8, p.690-695, 2006.

VAUTERIN, L.; HOSTE, B.; KERSTERS, K.; SWINGS, J. Reclassification of Xanthomonas. International Journal of Systematic Bacteriology, v.45, n.3, p.472-489, 1995. 